\title{
THE APPLICATION AND LIMITATIONS OF THE SEM-EDS METHOD IN FOOD AND TEXTILE TECHNOLOGIES*
}

\author{
Suzana Erić**
}

(REVIEW PAPER)

University of Belgrade, Faculty of Mining and Geology, Belgrade, Serbia

UDC 543.4:(641+677)

Compared to other methods of investigation, the scanning electron microscopyenergy dispersive spectrometry (SEM-EDS) method is significantly less frequently used in the study of the samples related to food and textile technologies. Food scientists most commonly use the SEM-EDS method to investigate the starch morphology of different plants as differences in the size and shape of starch granules may be attributed to the biological origin and physiology of the plant. In addition, these researchers manipulate the starch structure and control the interactions between starch and other food components to determine its effect on the rate of digestion. In textile technology, researchers use the SEM-EDS method to investigate contemporary antimicrobial textiles to assess their possible use in medical equipment as the means to avoid the spread of microbes. SEM-EDS method is often used for the purpose of biodeterioration in the study of historical textiles which have been colonized by microorganisms. However, the inability to analyze wet samples is the main limitation of the SEM-EDS method in the investigation of food samples. This limitation can be partially overcome by studying wet samples under low vacuum conditions, or by creating a non-conventional cross-section of fresh samples which, when covered with a gold layer, can be investigated under high vacuum conditions. Textile samples cannot be polished, which limits the use of this method in obtaining a quantitative chemical analyses. New possibilities of applying the SEM-EDS method in the investigation of food and textile samples should be considered because some limitations of this method can be partially exceeded.
Keywords: SEM-EDS method, food, textile technology, application, limitations

\section{Introduction}

A scanning electron microscope (SEM) is an instrument that allows the observation and characterization of materials within a $\mathrm{mm}$ to $\mathrm{nm}$ scale. In most cases, the SEM is connected to an energy-dispersive spectrometer (EDS), so there is the possibility of an elemental analysis showing chemical characteristics of the samples [1-4]. The SEMEDS method is applied in various fields of science: geology (especially mineralogy, crystallography, petrology, and paleontology), technology, metallurgy, biology, chemistry, medicine, pharmacy, dentistry, environmental protection, and other scientific disciplines. Recently, this method has also been used to investigate nanomaterials, food, and textile technology. In addition to scientists, SEM laboratories often have other clients who use this method to characterize or control their raw materials and products. In this paper, by citing the basic principles of this method and presenting various examples, we point out the possibility of applying the SEM-EDS method in food and textile technology. The limitations of this method are also considered.

\section{SEM-EDS method - basic principes}

Magnification of the most modern SEMs ranges from 5 to $300000 X$. For example, the necessary magnification for observation of a mosquito's eye is from 1500 to $5000 \mathrm{X}$, but a large number of bacteria types are observed at the magnification from 5000 to $10000 X$. The basic parts of the SEM include the following: an electronic top, a column, a detector for secondary electrons (SE), a detector for backscattered electrons (BSE), and a sample chamber (Figure 1). The first SEM feature to consider is the electronic top. Its function is to provide a powerful source of electrons, accelerate them in an energy range of 0.1 to $30 \mathrm{keV}$, and allow for scanning the surface of the sample with as many electrons as possible. How is this accomplished? In the electronic gun, there is a thermionic electron emitter. The most commonly found thermionic electron emitters are tungsten fibers and lanthanum hexaboride. The term thermionic emitter (filament) indicates that the emission of the electrons begins by warming. For example, a tungsten filament emits electrons when electrically heated to the temperature

\footnotetext{
* Plenary lecture at the $12^{\text {th }}$ Symposium with international participation "Novel Technologies and Economic Development"
}

\footnotetext{
** Author address: Suzana Erić, Faculty of Mining and Geology, Đušina 7, 11000 Belgrade, Serbia

E-mail: suzana.eric@rgf.bg.ac.rs

The manuscript received: August, 9, 2017.

Paper accepted: August, 18, 2017.
} 
of 2000-2700K. Since the emitted electrons expand, there is a Wehnelt cap in an electron gun that directs and controls the number of emitted electrons. Thus, directed electrons move towards the anode, which allows some of the emitted electrons to pass through and reach the column. An electron beam that misses an anode slot arrives at the column which contains a lens system. In the column itself, there are two types of lenses: condenser lenses and objective lenses. Their function is to reduce the initial projection of the electron beam to the final size of the beam that is directed onto the sample. For example, the amount of reduction for tungsten filaments is up to 5000 times. Scanning coils are located above the objective lenses and sweep a beam back and forth across the sample, row by row.

In the electron beam column, a vacuum is necessary so that the emitted electrons do not react with particles from the air. The low pressure in the microscope column is maintained by a multistage vacuum pump system which consists of a rotary pump, a turbomolecular pump, and an ion pump which achieve pressures of $10^{-1} \mathrm{~Pa}\left(10^{-3} \mathrm{mbar}\right)$, $10^{-2} \mathrm{~Pa}\left(10^{-4} \mathrm{mbar}\right)$, and $10^{-9} \mathrm{~Pa}\left(10^{-11} \mathrm{mbar}\right)$, respectively. A special valve maintains the ultra-low pressure in the column, while the pressure in the chamber can be increased to atmospheric levels when replacing the sample. High vacuum is constant and necessary in the microscope co- lumn, and only when initially placing or replacing the sample air can be released into the sample chamber. This is achieved by closing the valve which separates the column from the chamber. When placing or replacing the sample, the vacuum in the sample chamber is re-established.

Emitted electrons interact with the electrons in the sample, produce different detectable signals and can contain the information about the topography of the surface of the sample and its composition. Types of signal are SE, BSE and characteristic X-rays [1-4].

The interaction of the primary electron beam depends on the type of material and the strength of the beam, i.e., it depends on the acceleration voltage of the primary electrons. In a high density material, the interaction of the primary electrons with the material is a relative shallow in the ratio to the material with a lower density at the same beam strength. For example, the interaction of primary electrons with silver is about one micrometer from the surface, whereas this interaction in aluminum is significantly broader and deeper. The same is true if we have the identical material but a different acceleration voltage of primary electrons. For example, when the acceleration voltage of the primary electrons is $30 \mathrm{keV}$, the interaction with the sample will be broader and deeper in the ratio than the interaction at 10 keV for the same sample.
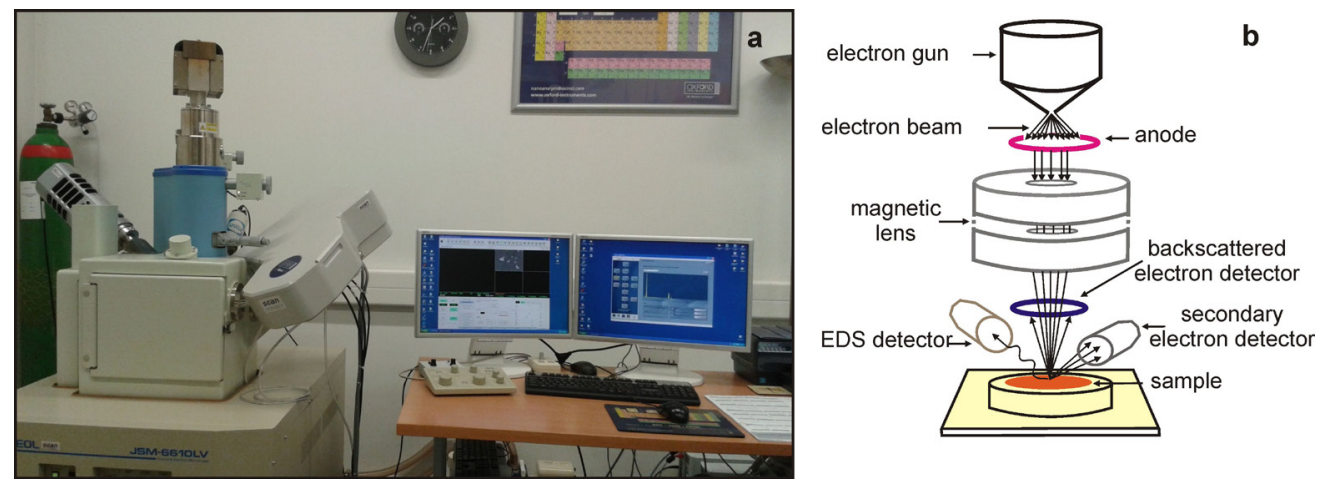

Figure 1. a) SEM Laboratory ${ }^{1}$ on UB-RGF b) schematic structure of SEM
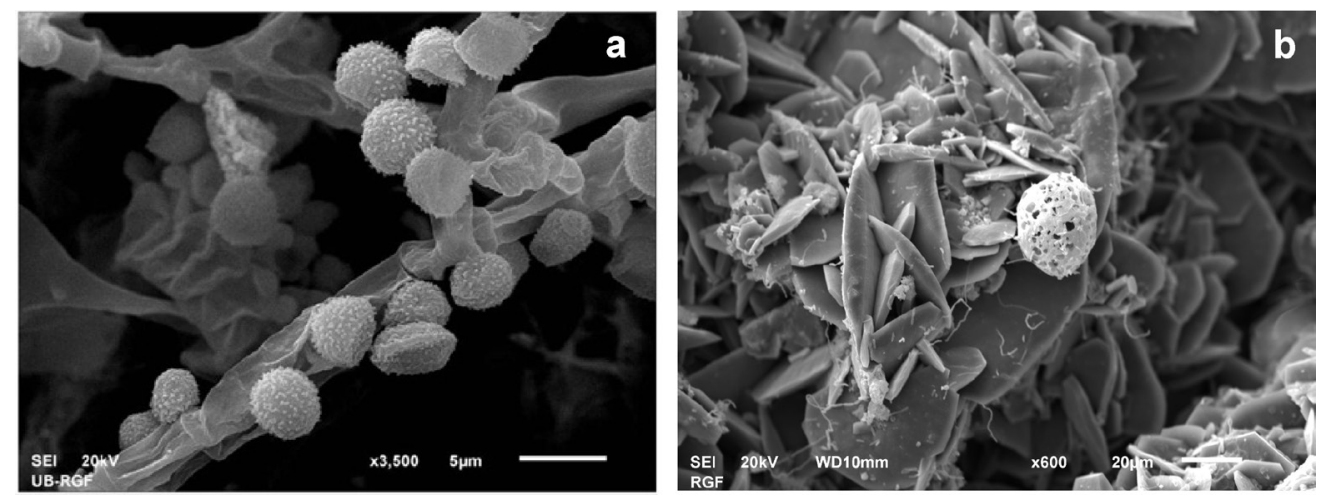

Figure 2. SE microphotographs ${ }^{2}$ of unpolished samples a) spore at the art picture [5], b) desert rose gypsum [6]

${ }^{1}$ The SEM laboratory of the Faculty of Mining and Geology (University of Belgrade) is equipped with a JEOL JSM-6610LV Scanning Electron Microscope that has the capability of operating under conditions of both high and low vacuum. This Scanning Electron Microscope is coupled with three detectors: X-Max Energy Dispersive Spectrometer, WDS detector - Oxford Instruments - model INCA Wave 700 and detector for Cathodoluminescence. The SEM lab is also equipped with a BALTEC-SCD-005 sputter coating device for covering the samples with gold or carbon

${ }^{2}$ All microphotographs in this paper have been obtained in SEM-laboratory from UB-RGF 
When the primary electron beam interacts with the sample, the energy exchange between the electron beam and the sample results in the emission of SE. SE are the result of an inelastic collision of primary electrons with the electrons from the sample, which causes an outburst of electrons from the sample and the electrons that caused the collision change its path and the energy. SE have low energy $(<50 \mathrm{eV})$ and are emitted from the area near the surface of the sample (several $\mathrm{nm}$ ), and they provide the information on the morphology of the sample. The examples of SE microphotographs are shown in Figure 2. Figure $2 a$ shows the morphology of the spore at the art picture [5]. Figure $2 \mathrm{~b}$ displays desert rose gypsum crystals with porous spherical carbon particles which occur on the walls of the King Gate at Kalemegdan [6].

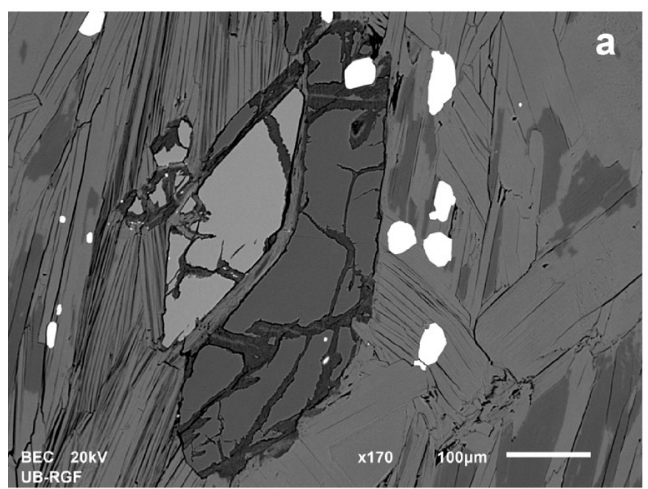

BSE are derived from elastic collisions of primary electrons with the electrons from the atoms of the sample. These electrons return in nearly the same direction from which they came and show a very small loss of energy. Chemical elements with higher atomic numbers produce many more BSE than those with smaller atomic numbers. Therefore, the sample area of the elements with larger atomic numbers appears to be brighter. This is called a phase contrast, and BSE are often used in the determination of chemically different phases. The examples of BSE microphotographs are shown in Figure 3. Figure 3a displays BSE of chemically different phases in mica schist, whereas Figure $3 \mathrm{~b}$ displays the chemical zonarity of pyrite grains [7].

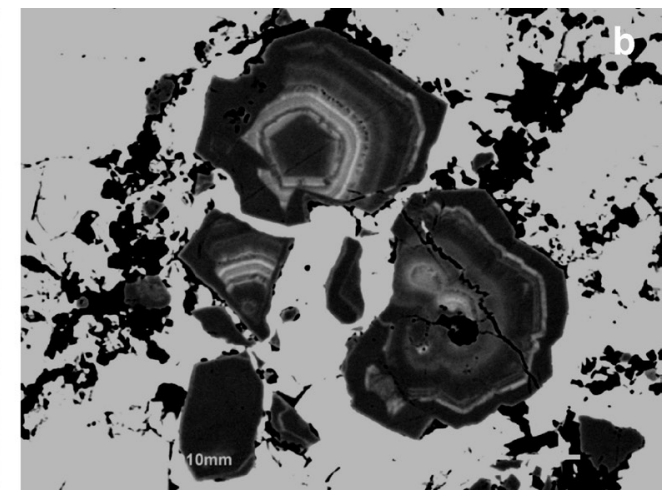

Figure 3. BSE microphotographs of polished samples a) phases in micaschist, b) chemical zonarity of pyrite grains [7]

Another type of signal occurs when the primary beam interacts with the sample. This consists of characteristic $\mathrm{X}$-rays which occur in the ionization process of the sample. To stimulate the emission of characteristic X-rays from the sample, high energy of electrons is directed at the test sample. In idle states, an atom inside the sample contains the basic state of the electrons on separate energy levels or electron shells connected to the core. The primary electron can excite an electron in the inner shell (for example, the $\mathrm{K}$ shell), expel it from the shell and create an electronic hole at the place where it was. The electron from the external, high-energy shell ( $L, M$...) then fills the existing place (hole), and the energy di-fference between the shell with higher and lower energy can be freed in the form of X-rays, i.e., the emission of energy in the form of the X-ray $\mathrm{K}$ series. X-rays are called characteristic because their energy is equal to the energy difference between the two levels involved in the transition; this difference is an identifying characteristic of each element.

As a type of spectroscopy, the EDS method relies on the sample research achieved through the interaction of electromagnetic radiation and the matter, i.e., the analysis of X-rays emitted from the matter in response to the stimulus of charged particles. The capabilities of these systems are largely based on the fundamental principle that each element has a unique atomic structure which allows X-rays to identify the characteristics of the elements as unique. EDS analysis is both effective and rapid for a qualitative chemical composition. The aim of the qualitative analysis is of course to find the elements present in an unknown pattern by identifying the characteristic X-ray lines of the spectrum. The EDS detector identifies the elements present in its program; however, due to its relatively low resolution, the results are sometimes ambiguous because of the overlap of the lines of two elements, for example Mo and S or Ag and Th. In order to obtain a good quantitative chemical analysis, several conditions must be met. First, a well-polished surface of the sample is needed and then, due to the geometry of the spectrometer or the best signal gathering, the working distance at which the focused part is to be analyzed must be exactly $10 \mathrm{~mm}$. The adequate accelerating voltage of the beam must be twice as high as the energy of the excitation of an element. For example, if the sample contains iron, whose energy of excitation is $7.11 \mathrm{keV}$, the accelerating voltage must be at least $15 \mathrm{keV}$ [1-4]. In order to obtain enough data, the analysis should take at least $100 \mathrm{~s}$. Additionally, standardization is necessary. Internal standards are an integral part of any EDS instrumentation and are useful only for a quick qualitative analysis, while external standards are necessary to obtain a reliable quantitative analysis. These standards are specially purchased, come with a chemical certificate 
and represent synthetic and natural minerals and metals. Prior to quantitative analysis under these conditions, we analyze the standards for the elements we expect to find or those that have been quickly identified by a qualitative EDS analysis.

Application of SEM-EDS method in food technology

Within the food technology field, SEM is most commonly applied in the investigation of the starch morphology of different plants. Namely, it turned out that differences in size and shape of starch granules may be attributed to the biological origin and physiology of the plant, and to the biochemical properties of chloroplast or amyloplast [8]. For example, there are studies about the effects of genotype and growing conditions on thermodynamic and structural properties of potato starches [9].
Moreover, it is known that some starch is resistant to enzymatic hydrolysis in the small intestine, but is fermentable by gut microbiota with health benefits of preventing colon cancer [10]. Therefore, the food scientists focus on manipulating the starch structure and on controlling the interactions between starch and other food components towards a slow digestion rate. The SEM-EDS method is useful for studying the structure and physicochemical properties of modified starches such as rice starches modified by heat-moisture treatments [11]. In addition, the SEM-EDS method can be used to study the size and distribution of starch grains in dough made from different cereal grains (Figure 4a), as well as starch on the surface of cereal grains (Figure 4b) ([12] and unpublished data of Nada Nikolić, University of Niš, Faculty of Technology, Leskovac).

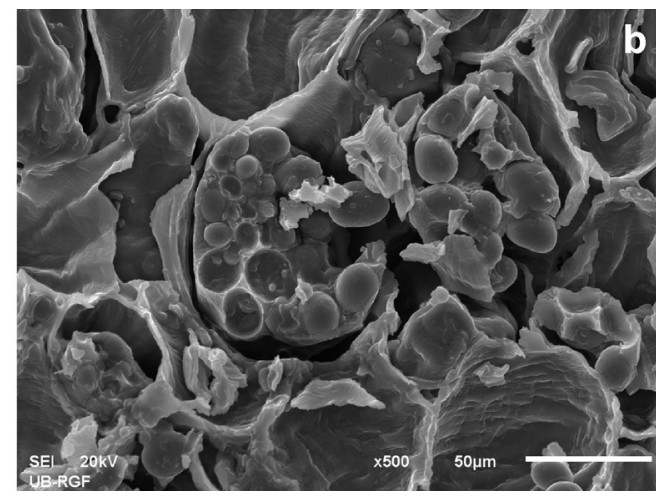

Figure 4. SE microphotographs of food samples a) starch in the dough made of lens grains, b) starch on the surface of cereal grains (unpublished data of Nada Nikolić, University of Niš, Faculty of Technology, Leskovac)

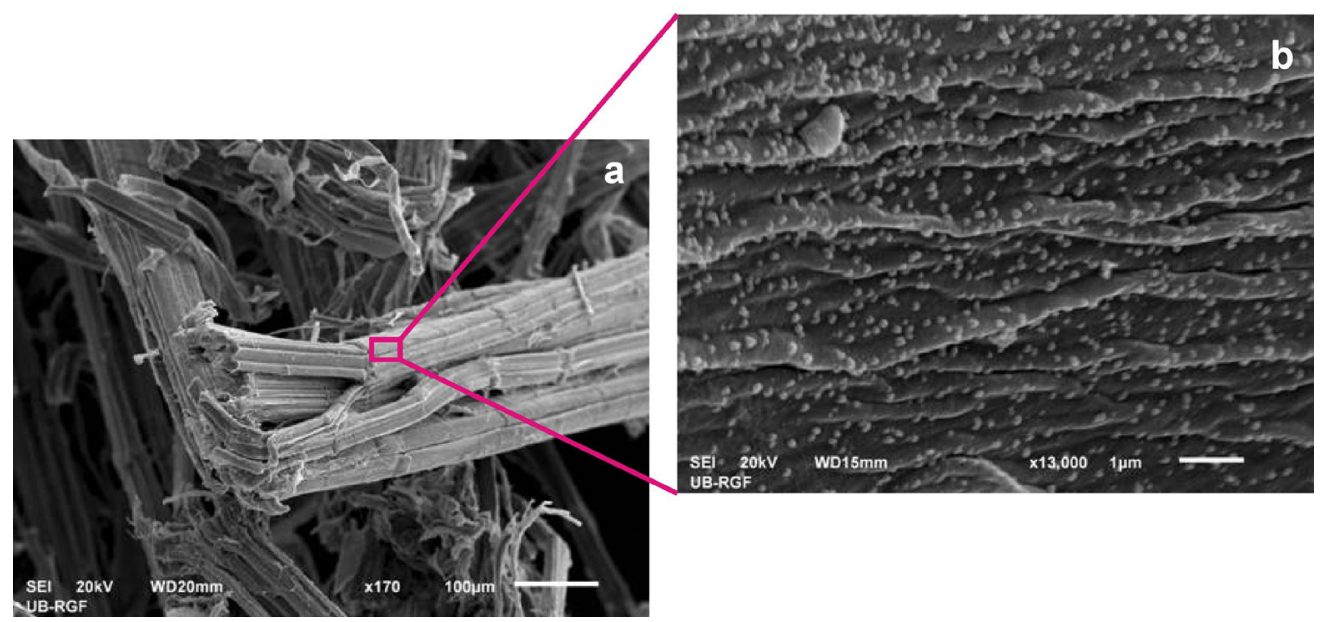

Figure 5. SEl microphotographs a) hemp fibers doped with silver, b) silver particals, detail [15]

Application of SEM-EDS method in textile technology In recent times, the SEM-EDS method has also been useful in the study of different types of textile materials. Historical textiles (natural fibers of plant and animal origin-cotton, flax, wool, silk, and others) are easily colonized by microorganisms, which leads to their biodeterioration. Thus, the effectiveness of low temperature plasma disinfection and its impact on cotton, linen, and silk can be clearly observed on the SEM images [13]. A large number of researchers investigate contemporary antimicrobial textiles. Cotton fibers impregnated with biogenic silver nanoparticles for example, have an antimicrobial characteristic which opens up the possibility for their use in medical equipment as means to avoid 
microbial spreading [14]. The SEM method allows monitoring of the size, shape, and distribution of these silver nanoparticles on textiles because of the possibility of observation under high magnification. One such example is a hemp fiber doped with silver (Figure 5a). With higher magnification SEM, the distribution and size of the silver particles on these fibers can be clearly seen (Figure $5 b)$ [15]. The SEM-EDS analysis is also applicable for studying the effects that different nanoparticles which are present as coatings $\left(\mathrm{TiO}_{2}, \mathrm{ZnO}\right)$ can have on textile properties.

\section{Limitations of application of SEM-EDS method in food} and textile technology

The limitations of the SEM-EDS method in the examination of food and textile samples are primarily related to the inability to analyze wet samples. In most cases, samples cannot be polished, thus making it impossible to obtain complete quantitative chemical analyses, but only semi-quantitative analyses. Also, the conventional preparation of the plant tissue for SEM investigations includes dehydration, which can remove or alter the surface wax [16]. However, these problems can sometimes be overcome by creating non-conventional samples, i.e., thin cross-sections of fresh, wet samples covered with a nano-scaled gold layer, which can be investigated under high vacuum conditions. In this manner, the size and distribution of stomata in fresh fruits, for example, the samples of prunes [17], can be routinely analyzed. Furthermore, new generations of SEMs provide better conditions for the investigation of wet samples under low vacuum conditions without covering them with an electroconductive material (e.g., gold, carbon).

EDS analysis can register the content of elements over $1000 \mathrm{ppm}$ with only certain degree of accuracy. As a result, this method is not suitable for analyzing the heavy metal content in plants. This type of analysis is adequate for macroelements. The content of microelements can be analyzed by other methods such as by inductively coupled plasma mass spectrometry (ICPMS). Also, to obtain the characteristics of a sample below its surface, the use of a transmission electron microscope (TEM) is required.

\section{Conclusion}

Researchers which investigate the samples within the food and textile technology should consider the possibility of greater application of the SEM-EDS method. The limitations of this method, such as the inability to analyze wet samples or the inability to prepare polished samples for the quantitative chemical analysis can be exceeded in a large number of cases.

\section{References}

[1] P. Echlin, Handbook of Sample Preparation for Scanning Electron Microscopy and X-Ray Microanalysis, Springer,
2009 , p. 200

[2] L .Reimer, Scanning electron microscopy: physics of image formation and microanalysis, Springer, 1998, p. 527.

[3] S.J.B. Reed, Electron Microprobe Analysis and Scanning Electron Microscopy in Geology. Cambridge University press, Second Edition, 2005, p. 189.

[4] J.I. Goldstein, D. Newbury, D. Joy, C. Lyman, P. Echlin, E. Lifshin, L. Samyer, J. Michael, Scanning Electron Microscopy and X-Ray Microanalysis, Plenum Press, Third Edition, New York, 2007, p. 689.

[5] A. Pavić, T. Ilić-Tomić, A. Pačevski, T. Nedeljković, B. Vasiljević, I. Morić, Diversity and biodeteriorative potential of bacterial isolates from deteriorated modern combinedtechnique canvas painting, International Biodeterioration \& Biodegradation, 97 (2015) 40-50.

[6] V. Matović, S. Erić, A. Kremenović, P. Colomban, D. Srecković-Batoćanin, N. Matović, The origin of syngenite in black crusts on the limestone monument King's Gate (Belgrade Fortress, Serbia) - the role of agriculture fertilizer, Journal of Cultural Heritage, 13(2) (2012) 175186.

[7] A. Pačevski, R. Moritz, K. Kouzmanov, K. Marquardt, P. Zivković, LJ. Cvetković, Texture and Composition of $\mathrm{Pb}$ Bearing Pyrite from the Coka Marin Polymetallic Deposit, Serbia, Controlled by Nanoscale Inclusions, Canadian Mineralogist, 50(1) (2012) 1-20.

[8] J. Singh, N. Singh, Studies on the morphological, thermal and rheological properties of starch separated from some Indian potato cultivars, Food Chemistry, 75 (2001) 67-77.

[9] L. A. Wasserman, A. I. Sergeev, V. G. Vasil'ev, I. G. Plashchina, N. P. Aksenova, T. N. Konstantinova, S. A. Golyanovskaya, L. I. Sergeeva, G. A. Romanov, Thermodynamic and structural properties of tuber starches from transgenic potato plants grown in vitro and in vivo, Carbohydrate Polymers, 125 (2015) 214-223.

[10] K.M. Behall, D.J. Scholfield, J.G. Hallfrisch, H.G. LiljebergElmståhl, Consumption of both resistant starch and -glucan improves postprandial plasma glucose and insulin in women, Diabetes Care, 29 (2006) 976-981.

[11] X. Chen, X. He, X. Fu, B. Zhang, Q. Huang, Complexation of rice starch/flour and maize oil through heat moisture treatment: Structural, in vitro digestion and physicochemical properties, International Journal of Biological Macromolecules, 98 (2017) 557-564.

[12] N. Nikolić, J. Dodić, M. Mitrović, M. Lazić, Rheological properties and the energetic value of wheat flour substituted by different shares of white and brown flour, Chem. Ind. Chem. Eng. Q. 17 (3) (2011) 349-357.

[13] J. Szulc, W. Urbaniak-Domagała, W. Machnowski, H. Wrzosek, K. Łacka, B. Gutarowska, Low temperature plasma for textiles disinfection. International Biodeterioration \& Biodegradation, (2017) http://dx.doi. org/10.1016/j.ibiod.2017.01.021.

[14] D. Ballottin, S. Fulaz, F. Cabrini, J. Tsukamoto, N. Durán, O,L. Alves, Lj. Tasic, Antimicrobial textiles: Biogenic silver nanoparticles against Candida and Xanthomonas, Materials Science and Engineering C, 75 (2017) 582-589.

[15] J. Milanović, T. Mihailović, K. Popović, M. Kostić, Antimicrobial oxidized hemp fibers with incorporated silver particles, Journal of the Serbian Chemical Society, 77 (12) (2012) 1759-1773.

[16] S. Roy, W.S. Conway, A.E. Watada, C.E. Sams, E.F. Erbe, W.P. Wergin, Changes in the ultrastructure of the 
epicuticular wax and post harvest calcium uptake in apples, Scientia Horticulturae, 34 (1999) 121-124.

[17] A. Konarska, Micromorphological, anatomical and ultrastructural analyses of ovaries and fruit lets indicate early qualitative differences in two Prunus domestica cultivars, Scientia Horticulturae, 189 (2015) 112-121.

Izvod

\section{PRIMENA I OGRANIČENJA SEM-EDS METODE U TEHNOLOGIJI HRANE I TEKSTILA}

Suzana Erić

(PREGLEDNI RAD)

UDK 543.4:(641+677)

Unverzitet u Beogradu, Rudarsko-geološki fakultet, Beograd, Srbija

Metoda skenirajuće elektronske mikroskopije sa energo-disperzivnom spektrometrijom (SEM-EDS) se u poređenju sa drugim metodama istraživanja mnogo manje koristi u studijama koje su vezane za tehnologije hrane i tekstila. Naučnici koji se bave tehnologijom hrane najčešće koriste SEM-EDS metodu za ispitivanje morfologije skroba različitih biljaka, jer se razlike u veličini i obliku skrobnih granula mogu pripisati biološkom poreklu i fiziologiji biljaka. Pored toga, ovi istraživači manipulišu strukturom skroba i kontrolišu interakcije između skroba i drugih sastojaka hrane da bi se utvrdili njegov uticaj na brzinu varenja. U tekstilnoj tehnologiji mnogi istraživači koriste SEM-EDS metodu za istraživanje savremenog antimikrobnog tekstila kako bi procenili moguću upotrebu u medicinskoj opremi kao sredstva za izbegavanje širenja mikroba. SEM-EDS metoda se takođe često koristi kod biodeterioracije, u istraživanju mikroorganizmima kolonizovanih istorijskih tekstila. Međutim, nemogućnost analize vlažnih uzoraka je glavno ograničenje SEMEDS metode kod istraživanja uzoraka hrane. Ovo ograničenje se može delimično prevazići proučavanjem vlažnih uzoraka pod uslovima niskog vakuuma ili pravljenjem nekonvencionalnih poprečnih preseka svežih uzoraka koji se naparavaju slojem zlata i onda mogu ispitati pod uslovima visokog vakuuma. Uzorci tekstila se ne mogu polirati pa se umesto kvantitativnog može dobiti samo semi-kvantitativni hemijski sastav. Trebalo bi razmatrati nove mogućnosti primene SEM-EDS metode $u$ istraživanju uzoraka hrane i tekstila, jer se neka ograničenja ove metode mogu delimično prevazići.
Ključne reči: SEM-EDS metoda, hrana, tehnologija tekstila, primena, ograničenja 